\title{
Abuse of Authority: A Meaning Deconstruction
}

\author{
Kurnia Dewi Anggraeny ${ }^{1}$ \\ 1 Universitas Ahmad Dahlan, Indonesia \\ kurniadewi@law.uad.ac.id
}

\begin{abstract}
Introduction to The Problem: As part of the organization of the government duties and community services, the authority to make a decision is attributed to the government officials (inherent aan het bestuur), which has led many to become a suspect and a convict. On the other hand, it is believed that the government's policies are not subject to the law. This paper analyze abuse of authority according to a meaning deconstruction.

Purpose/Objective Study: This study aims to determine to analyze abuse of authority according to a meaning deconstruction

Design/Methodology/Approach: The research applied normative juridical approach as the logical consequence of sui generis of law.

Findings: Each network of a structure of meaning is always presented in the form of binary opposition. One of the elements is marginalized and abandoned. Similarly, in the field of law, the term "abuse of authority," which is often connected to the damage that occurs to the state's financial condition, is seen as an absolute part of the Criminal Law. Arbitrarily, it replaces the function of the State Administrative Law. The "financial loss," which is then known as corruption, is the result of 'abuse of authority,' originated from the State Administrative Law. Through Jacques Derrida's perspective, a marginalized binary opposition is made into being. It is not to dominate others, but to share the views. The disjuncture between the state administrative law and criminal law has caused an unresolved issue of corruption. Through Paul Scholten's perspective, in essence, the criminal law has abandoned the social fact that there is a strong correlation between the deeds in the state administrative law and those in the criminal law, which is in the theoretical domain of administrative criminal law. The abandonment is against the hulprecht principle related to the implementation of the law mentioned above. The research employed a normative juridical method based on secondary data using philosophical, conceptual, and legal approaches.
\end{abstract}

Originality: This article discusses specifically abuse of authority, a meaning deconstruction in terms of criminal law and state administrative law

Paper Type: General Review

Keywords: Abuse of Authority, Deconstruction, Corruption

\section{Introduction}

The concept of state law is defined as supreme, where every action should be based on the law (Muntoha, 2009). Mochtar Kusumaatmadja stated that the definition of state law is a state which is based on law, where the power is rooted in law, and everyone is equal before the law (Kusumaatmadja, 2002). Every graduate of law, either an academics or a 
practitioner, clearly understands the principles. In the present research, the problem presented is related to how the graduates comprehend the meaning of "law." Further, the question goes to what kind of principles understood by the graduates.

The history of the state of law contains conceptual development. Padmo Wahyono explained the shift in the paradigm of development, starting from the Formal State of Law by Stahl into The Material State of Law. There was a change in the elements of wetmatig bestuur into rechtmatig bestuur, into sosiale verzorgingsstaat or social service state, by changing rechtmatig into doelmatig (Wahyono, 2017). It means the understanding of the word "legal" is no longer based on the classical meaning, which was Laws or regulations. Instead, philosophically, the state exerts authority and is subject to the legal provisions. When law exists in a country, the authority is controllable, and it runs based on written or conventional law (Malik, 2013).

The development of the meaning of the law as a closed system, or the classic/formal concept, still dominates and rules the law graduates in Indonesia. Satjipto Rahardjo explained that law is always introduced to the bachelor candidates as a system of regulations arranged logically and consistently. Usually, the definition is added by the concept of "closed system," for the core concepts learned are the positive laws. The science of law is treated as a deductive science. The aim is to implement the regulations to the daily events in society (Rahardjo, 1981).

Based on the explanation, "the principle of legality" becomes the belle in the process of criminal legal enforcement in Indonesia. The principles of legality are not the only ones contributing to the perspective of autonomous legal science ramification into criminal law. There are several other principles to know, such as "autonomie van het materiele straftcrecht" (autonomous right of material criminal law) issued by the administrative law, a demeersemen from the Dutch.

According to Chairul Huda, the one explaining about autonomie van het materiele strfrecht, criminal law holds an autonomous right to determine the meaning. However, if the criminal law does not provide a distinguished definition, the one provided by other law can be used (Christianto, 2017). In Indonesia, the implementation has been approved by the Supreme Court through a Decree of the Supreme Court Number 1340 K/Pid/1992 dated 17 February 1992, jo The Decree of the Supreme Court Number 977 K/Pid/2004 jo the Decree of the Supreme Court Number 979 k/Pid/2004.

Laws Number 31/1999 on the Eradication of Corruption as amended by the Laws Number 20/2001 on The Amendment of the Laws Number 31/1999 on Eradication of Corruption presupposes the concept of "abuse of authority." The study focuses on one of the elements to prove the actions that are "against the law," particularly corruption, of which the subjects are the State Civil Apparatus.

The main characteristics of the criminal sanction are to provide a legal guarantee to the society, in that the government officials in accomplishing the duties and functions in the 
frame of a welfare state are to achieve the purpose of the country: the public welfare. The sanction is intended for the government officials having the power and authority, whose duties and functions are related to the life of the society. Similar to a standard sanction, an action is considered against the law in the criminal context. In relation to the Government Officials as the legal subject of the State Administrative Law, the parameter for the evidence is the abuse of authority (de tournement pouvoir or onrechtmatige overheidsdaad).

As part of the organization of the government duties and community services, the authority to make a decision is attributed to the government officials (inherent aan het bestuur), which has led many to become a suspect and a convict. On the other hand, it is believed that the government's policies are not subject to the law. Arifin P. Soeria Atmadja proposed that a policy cannot be presented before the court because it does not hold any legal basis nor a subject to criminal law. It is due to the fact that a particular policy does not apply at the same time as another, or it has not been regulated (Pitriyantini, 2019).

\section{Methodology}

The research applied a normative juridical approach as the logical consequence of sui generis of Law. The normative juridical approach is the approach taken based on the main legal material by examining theories, concepts, legal principles and laws and regulations related to this research (Sonata, 2015). However, the method only bases on secondary data or prescriptive. Besides, it contains two major weaknesses; those are the inability to reach the linguistic phenomena and reduction of transcendental elements of human. For this, Johnny Ibrahim provided an alternative to anticipate the drawbacks (Ibrahim, 2006). Those are by employing other approaches, such as philosophical, semiotics, and critical.

\section{Results and Discussion}

\section{Jacques Derrida's Deconstruction Theory}

Jacques Derrida is a French philosopher, although he was born in El Biar, Algeria. Derrida's philosophical ideas were highly influenced by Edmon Husserl's phenomenology and Ferdinand de Saussure's structuralism. Derrida is classified into the "postmodernism" philosopher. As known previously, the postmodernism is from a group of philosophers sending their criticism to modernism that appeared after the Middle Ages (Dark Ages) for their positivistic concepts.

The Western philosophers listed as Modernists were trapped in the logocentrism tradition. It means the full belief on logos or ratio. The outstanding characteristics of the tradition are the tendency to think about hierarchical binary opposition (essence, existence, substance, accident, soul/body, meaning, form, transcendent, empiric, positive/negative, spoken or written, concept/metaphor, and so on), considering that the first element as the central, the origin, the foundation, principle, and undoubted being. Meanwhile, the second element is the derivation and the side manifestation of the first (Pradoko, 2017).

Marcelus Ungkang explained that the practice of binary opposition is where one of the elements is privileged, while others are marginalized. Both elements are arranged based on 
particular limitations distinguishing one from another (Ungkang, 2013). The binary opposition is the core of the system of difference being the foundation of the structural thought. The western philosophy based their concept on this binary opposition. A simple example of a hierarchical binary opposition is the "signifier" will be opposed to the word "false" (true/false) male vs female (man/woman).

Investigating the issues, Derrida was triggered to carry out a deconstruction of western philosophy. Deconstruction means dismantling, but it does not refer to a demolition that ended in monism or emptiness. Further, it is not an interpretation method completed with a set of argumentative and anti-coherent concepts. Indeed, deconstruction is opposed to anti-method, anti-argumentation, and anti-coherence, because it is scientific, or positivistic (Turiman, 2015).

The opposition in linguistics goes hand in hand with the western philosophy. In the binary opposition, the first terms are the master, which is superior to the second, the subordinates/employee. Meanwhile, the second terms are the unreal representations of the first or the inferior. The tradition is called logocentrism. It is used to explain the assumption of a privilege attributed to the first term and "disgrace" to the second (Norris, 2017). Derrida's deconstruction aims to reveal the binary opposition in presenting and showing the inferior elements as necessary to consider.

The strength of Derrida's concept is the efforts to find alternative values amidst the existing ones. It encourages the dynamics and stimulates human to seek better, appropriate, and indepth values. This way, it is expected they can answer the underlying issues of humanity. Derrida aimed to bring awareness and to be the spokesperson for the marginalized, isolated. They will speak on behalf of those who want pluralism, relative truth, and unique dwelling (Turiman, 2015).

Therefore, Derrida's deconstruction using semiotics method aims to diminish all boundaries of strict interpretation or conclusion. The concept reveals the product of rational thought, believing the purity of reality (Rhiti, 2016).

\section{The Overlapping of Criminal Law and State Administrative Law}

Indonesian criminal law since the independence day was signified by the three stages of development in criminal law and criminalization. First is retaining the criminal law applicable since the colonial era with several adjustments as the law applied in Indonesia after independence. Second is positioning the Criminal Code as national criminal law and preventing the development of another kind of criminal law outside the applicable laws, except the ones under the administrative law. And third is developing the criminal law outside the provision of the Criminal Code and establishing the system of criminal law and separated criminalization from the principles of the national law, as mentioned in Book 1 of the Penal Code (Mudzakkir, 2008).

A sanction is a form of sentencing given by those holding power and authority based on the laws and regulations. Reviewing the type and form of the sanction are depends on the legal 
domain. The criminal sanction, which is unique to public law, consists of two forms: imprisonment and fines. However, in general, the criminal sanction is stereotyped as a form of imprisonment. The statement leads to the interpretation that criminal imprisonment is identical to criminal law. There is no right or wrong on the matter.

As confirmed by A.Z Abidin and Andi Hamzah, As confirmed by A.Z. Abidin and Andi Hamzah, the public law, which also includes criminal law, is related to the public interest. The violation of law is committed not by a person but by the state and the apparatuses. Personal interest in the form of compensation is neglected. Instead, the emphasis is on the sanction in the form of policy and action (Yahya, 2005). The context is no longer suitable for the development, for there has been a particular modification with an interdisciplinary approach based on the broadened interest. One example of the modification is the addition of criminal sanctions into the state administrative law.

The regulation takes the root of the perception that crime is a behaviour that violates the law and social norms, which is against the society. In the social context, crime is a social phenomenon occurring at any time and place (Sahetapy, 1991). Responding to the phenomena, Barda Nawawi Arief showed that crime causes problems not only to a particular society, either local or national, but also to the people around the globe, in the past, present, and future. In other words, crime is a universal phenomenon (Luthan, 1995).

The government's intervention should stand on the applicable laws and regulations as the manifestation of the principles of legality, the fundamentals of state law. In a particular condition, the government can take any action without relying on the regulations. Instead, they can take their initiative through personal discretion. Unfortunately, it causes anxiety among the public because discretion tends to create a conflict of interest between the government and the people. According to Sjachran Basah, the government, in performing the activities, especially in realizing the state's goals through development, must not act without reasons. The government should hold responsibility for each decision (Rahmat, 2014).

Meanwhile, Sudarto, whose ideas were correlated with the one proposed by E. Utrecht, mentioned that the criminal law protected the interests maintained by the private law or the ones by public law through a specific sanction. The sanction is necessary, especially when the government needs to enforce the sanctions more potent than the one imposed by the privacy laws (Yahya, 2005). Therefore, imprisonment sanction can be added to the state administrative law.

About the criminal sanction, Herbert L. Packer suggested (Charles \& Packer, 1970), "...punishment is a necessary but lamentable form of social control. It is lamentable because it inflicts suffering in the name of goals whose achievement is a matter of chance". Here, although Packer recognized that criminal sanction as necessary, it is still considered a social control because it can cause the convict to suffer. Hyman Gross explained that criminal punishment is the worst permitted by law. He was an enthusiastic practitioner and granted himself an exclusive right. Apart from the patronage, numerous writing had been done in 
the efforts to justify the criminal law institution. However, there was no conclusion saying that that kind of social practice cannot be justified (Gross, 2012). Hyman Gross confirmed that criminal sanction should contain a regrettable necessity because it can cause suffering. Therefore, justification is needed (Marsha, 2011).

A justification for a criminal sanction came from the idea that it is a debatable discourse about the theoretical and philosophical reasoning for the sanction. Roeslan Saleh confirmed that the thought of criminal punishment is not perfect and complete if it is separated from the philosophy. Criminal liabilities are an integral part of two philosophical aspects: fairness and behaviour (Candra, 2013). It means that the formulation of criminal sanction of a particular deed is not based only on the theoretical reviews, but also on philosophical related to the behaviours (acts categorized as a criminal act, considering the fairness aspect as the domain of philosophical review.

The inclusion of criminal sanctions in the state administrative law has to have purposes. Theoretically, the use of criminal sanctions in the state administrative law brings about a mixed legal domain, which is administrative criminal law. The aim of criminal law and one of state administrative law intervene and influence each other, and they create a new aim.

Terminologically, Barda Nawawi Arief reviewed in detail the transformation between criminal law and the state administrative law. He stated that administrative criminal law is said to be a criminal law in administrative law violations." Therefore, "the administrative crime" is stated as: "An offense consisting of a violation of an administrative rule or regulation and carrying with it a criminal sanction." Administrative law is regulatory rules, which are established in implementing the regulatory powers. Therefore, administrative criminal law is often called as criminal law about the regulation or the criminal law of rules (ordnungstrafrecht/ordeningstrafrecht). The term administrative law is also related to governance (therefore, the term "state administrative law" is also known as "governance law." Similarly, the term "administrative criminal law" is called "government criminal law" or Verwaltungsstrafrecht (verwaltungs is administration/government) and Bersuursstrafrecht (bestuur is government) (Rustamaji, 2019).

Other legal experts proposed the definition of administrative criminal law. For example, Mardjono Reksodiputro explained that the modern country's responsibilities are to protect the public welfare, to establish various kinds of regulations, such as safety health at work and settlement, as well as in food processing and medicines. The regulations can include civil sanctions or administrative sanctions, but there is a strong tendency to regulate through criminal sanctions. The latter is often called administrative penal law or verwaltungsstrafrecht. Here, the concept of strict liability is used (Reksodiputro, 2017). Similar to Mardjono Reksodiputro, Muladi explained the functions, duties, and purposes of criminal law in the framework of provisioning the government tools in the modern and globalization era. According to Muladi, criminal law, in terms of national economic development, is used to increase the accountability of the state in managing public life. Further, criminal law is used for the maximum benefits to support the administrative legal 
norms in various aspects of life. This is what is called administrative penal law (verwaltungsstrafrecht), which is included in the public welfare offenses (ordnungswidrigkeiten) (Hosnah, 2020).

There are two kinds of formulation of criminal norms and the criminalization mentioned in the Criminal Code, including the categories of criminal law, public criminal law, or administrative law. The first is following the general provision of Book 1 of the Penal Code, while the second is the pattern mentioned in the laws. The latter usually has an inconsistent pattern, resulting in the disparity in enforcing the criminal sanction, either for general or specific criminal threats (Mudzakkir, 2008).

Consequently, the regulation should be returned to the original intention. Referring to French experts, such as Macarel, de Gerando, and Trolley, it is known that administrative law regulates individuals' interest concerning the state. Romeyn mentioned that criminal law serves as "supporting law" or hulprecht for the administrative law (Rahmat, 2014), meaning that a criminal sanction always accompanies each provision in the State Administrative Law (Rahmat, 2014).

\section{Analysis}

Before discussing the issues, there are several postulates revealed in the introduction, which become the basis of the reasonings. For example, is the one proposed by Andi Hamzah about the advances of several aspects of life as the result of globalization has added to the patterns of crime and criminalization within a country. It is indicated by the interaction among countries and between a country and the world's organizations. It strengthens the fact that the criminal law of a nation is the reflection of the state civilization (a mirror of the civilization of a nation) (Hamzah, 1995).

The principles of legality are far from the original meaning, which is to protect the abuse of authority by the rulers. Besides, the shift takes several other forms, such as the accommodation of "autonomie van het materielle strafrecht" by the Supreme Court and the establishment of retribution for criminal law politics. The acceptance of all the postulates by most of the Law Graduates through the teaching materials is a process of hegemony, as illustrated by Michael Foucault.

In essence, criminal law does not have any basic concept of abuse of authority. Unfortunately, it has not been able to distinguish the concept of 'power' from 'authority,' nor' discretion.' In general, another question to ask is whether criminal law can distinguish power and authority.

The concepts of power, authority, and competence, as well as discretion, are the core of state administrative law. The inabilities are abandoned through "autonome van her materielle strafrecht." Besides, the political determination of legal enforcement for corruption as mentioned in the explanation of the Laws number 31/1999 (The provision for "reversal burden of proof") needs to be added into the Laws Number 31of 1999 on Corruption Eradication as the provision with 'premium remidium.' 
Semiotically, there is a simplification upon the 'recognition' of the sophisticated case of corruption occurring nowadays. From the paradigmatic point of view, there was a kind of thrownnes (gowerfen-sen) upon the classic paradigm requiring a closed and autonomous as well as a value-free point of view.

The development of the studies about corruption is comparable with the international convention. However, the comparison should pay attention to the ramification of law science and the specification of the judiciary.

Since power is an inherent legal instrument of a particular position, it is necessary not to create any fragment of the legal entity as a whole. Paul Scholten proposed that law is the whole rules and powers set in a logical arrangement. Yet, it is subject to changes and open to any kind of society within a particular period (Manullang, 2019). Further, E.Utrecht explained that each regulation of law is correlated. The rules of law do not stand on their own, but they have their place within the legal domain. The particular place is the consequence of interdependence, which is a social phenomenon. Several rules containing similarities in the elements or the objectives are the sets of particular regulations and are known as innerlijke samenhag (internally intertwined) (C.S.T. Kansil, 2014). The definition of the phrase means that human social phenomena have brought about various rules. The regulations, which appeared from the social phenomena, tend to overlap.

At this point, it is clear that we cannot marginalize the binary opposition therein. The domination and hegemony of criminal law in law enforcement over the perpetrators of corruption become partial without finding the solution for the fundamental problem. It should be admitted that the core of the problem is about an official being accountable to his position.

The ambiguity of the Criminal Law is evident in the pursuance of a partial legal certainty. The portion, which is based on the principles of legality, contains a distance and distinguishing aspects of a meaningful life through legal normalization, which is by leaving the certainty of its legal concepts.

In the context of the philosophy of science, approaching a particular norm cannot be done by abandoning the concepts that bring up the norm. Otherwise, it will be a logical fallacy (Weruin, 2017). Derrida's perception of a text cannot be separated from the whole horizon, internal or external, physical or metaphysical. It cannot be denied that an official is also a dualism being: rational and transcendental.

The justification for articles 50 and 51 of the Criminal code indicates legal protection for the abuse of authority, particularly in cognitive interpretative activities. The question was about which court has the authority to examine the 'statutory orders' and the 'position orders.'

The answer to the question would be Laws Number 5 of 1986 on the State Administrative Procedure Law, but the writer did not take the preference. The laws, indeed, was not set to be a general administrative law. 
The problem can be solved through a normative juridical approach. When a question appears about the concept of 'power,' 'authority,' and 'free power (discretion),' the easy answer is the Laws Number 30 of 2014 on Government Administration.

The development of the legal domain has challenged the legislative power to prevent any criminalization of the official positions. It needs to think about the 'abuse of authority' attributed inherently to a particular position, mentioned in the Laws Number 31 of 1999 jo Laws number 21 of 2001. From the normative juridical approach, Laws Number 30 of 2014 has instructed to examine the 'abuse of authority' through the State Administrative Procedural Law.

\section{Conclusion}

Based on the explanation, it can be concluded that the enforcement of the criminal law to corruption crime has been in thrownness (gowerfen-sein) in the classic paradigm to emphasize on imprisonment. The financial loss is an issue proving that the state should gain it back. The principles of premium remidium mentioned in Law number 31 of 1999 encourage the society to take revenge on a particular thing.

It is necessary to comprehend that the bureaucratic system or the state administration is indeed the cause of corruption. Derrida's perspective is acceptable, in that it reveals all the interpretation of all the elements causing criminal crime, which were previously in the domain of state administrative law.

\section{References}

C.S.T. Kansil, C. S. T. K. (2014). Pengantar ilmu hukum dan tata hukum Indonesia. In Profesional Psychology. https://doi.org/10.1163/_q3_SIM_00374

Candra, S. (2013). Pembaharuan hukum pidana; konsep pertanggungjawaban pidana dalam hukum pidana nasional yang akan datang. Jurnal Cita Hukum. https://doi.org/10.15408/jch.v1i1.2979

Charles, W. H. R., \& Packer, H. L. (1970). The limits of the criminal sanction. The University of Toronto Law Journal. https://doi.org/10.2307/825412

Christianto, H. (2017). Pembaharuan makna asas legalitas. Jurnal Hukum \& Pembangunan. https://doi.org/10.21143/jhp.vol39.no3.1512

Gross, H. (2012). Crime and punishment: a concise moral critique. in crime and punishment: a concise moral critique. https://doi.org/10.1093/acprof:oso/9780199644711.001.0001

Hamzah, A. (1995). Perbandingan hukum pidana. Sinar Grafika.

Hosnah, A. (2020). Diskresi dalam perspektif hukum pidana. Justicia Sains: Jurnal Ilmu Hukum, 4(2), 134. https://doi.org/10.24967/jcs.v4i2.480

Ibrahim, J. (2006). Teori dan metode penelitian hukum normatif. Bayu Media, Malang.

Kusumaatmadja, M. (2002). Konsep-konsep hukum dalam pembangunan - fungsi dan perkembangan hukum dalam pembangunan nasional. Teori Hukum Pembangunan.

Luthan, S. (1995). Kebijakan legislatif dalam penanggulangan kejahatan dengan pidana penjara. Jurnal Hukum Ius Quia Iustum. 
https://doi.org/10.20885/iustum.vol2.iss4.art7

Malik, M. (2013). Perppu pengawasan hakim MK versus putusan final MK. Jurnal Konstitusi, 10(4), 579-604.

Manullang, F. M. (2019). Kritik terhadap struktur ilmu hukum menurut Paul Scholten. Jurnal Hukum \& Pembangunan. https://doi.org/10.21143/jhp.vol49.no1.1909

Marsha, I. (2011). Crime and criminal justice. In Crime and Criminal Justice. https://doi.org/10.4324/9780203833780

Mudzakkir. (2008). Perencanaan pembangunan hukum nasional bidang hukum pidana dan sistem pemidanaan (politik hukum dan pemidanaan). Badan Pembinaan Hukum Nasional.

Muntoha, M. (2009). Demokrasi dan negara hukum. Jurnal Hukum Ius Quia Iustum. https://doi.org/10.20885/iustum.vol16.iss3.art4

Norris, C. (2017). Deconstruction. in companion to literary theory. https://doi.org/10.1002/9781118958933.ch8

Pitriyantini, P. E. (2019). Peraturan kebijakan yang menimbulkan kerugian keuangan negara sebagai unsur tindak pidana korupsi. Jurnal Komunikasi Hukum (JKH). https://doi.org/10.23887/jkh.v5i2.18332

Pradoko, A. M. S. (2017). Pembelajaran kritis dekonstruksi derida, pemahaman teks pedagogi kritis. In Sastra: Merajut Keberagaman Kebangsaan.

Rahardjo, S. (1981). Manfaat, telaah sosial terhadap hukum. Jurnal Hukum \& Pembangunan. https://doi.org/10.21143/jhp.vol11.no1.840

Rahmat, M. (2014). Hukum administrasi negara Indonesia. Hukum Administrasi Negara Di Indonesia.

Reksodiputro, M. (2017). Pendidikan hukum di Indonesia. Jurnal Hukum \& Pembangunan. https://doi.org/10.21143/jhp.vol19.no6.1182

Rhiti, H. (2016). Landasan filosofis hukum progresif. Justitia et Pax. https://doi.org/10.24002/jep.v32i1.760

Rustamaji, M. (2019). Biomijuridika: Pemikiran ilmu hukum pidana berketuhanan dari Barda Nawawi Arief. Undang: Jurnal Hukum. https://doi.org/10.22437/ujh.2.1.193223

Sahetapy, J. E. (1991). Hukum dan keadilan. Jurnal Hukum \& Pembangunan. https://doi.org/10.21143/jhp.vol21.no1.393

Sonata, D. L. (2015). Metode penelitian hukum normatif dan empiris: karakteristik khas dari metode meneliti hukum. FiatJustisia. https://doi.org/10.25041/fiatjustisia.v8no1.283

Turiman, T. (2015). Metode semiotika hukum jacques derrida membongkar gambar lambang negara Indonesia. Jurnal Hukum \& Pembangunan. https://doi.org/10.21143/jhp.vol45.no2.6

Ungkang, M. (2013). Dekonstruksi Jaques Derrida sebagai Strategi pembacaan teks sastra. Jurnal Pendidikan Humaniora. https://doi.org/10.17977/JPH.V1I1.3919

Wahyono, P. (2017). Bagaimana membangun dan membina hukum nasional. Jurnal Hukum \& Pembangunan. https://doi.org/10.21143/jhp.vol16.no2.1195

Weruin, U. U. (2017). Logika, penalaran, dan argumentasi hukum. Jurnal Konstitusi. https://doi.org/10.31078/jk1427 
Volume 11, Issue 02, 2020, pp. 130-140

P-ISSN: 1412-6834

E-ISSN: 2550-0090

Yahya, N. (2005). Resensi Buku: Hukum pidana. Perspektif. https://doi.org/10.30742/perspektif.v2i2.162 